\title{
ARCHITECTURAL SCULPTURE
}

\section{ARCHITEKTONICZNA RZEŹBA}

Abstract

The paper presents the links between the different fields of art: painting, music, sculpture and architecture. The great influence of expressionist sculpture on architecture is emphasized. Modern buildings often look like built monuments. Architects like Zaha Hadid and Frank Ghery can distance themselves from their predecessors, but it seems to be evident that they unintentionally continue what was 'born' in the early twentieth century.

Keywords: architecture, expressionism, new forms

Streszczenie

Tekst stara się pokazać powiązanie różnych dziedzin sztuki: malarstwa, muzyki, rzeźby i architektury. Wpływ, jaki rzeźba ekspresjonistyczna miała na architekturę, jest wielki. Współczesne budynki wyglądają niekiedy jak zbudowane pomniki. Architekci, tacy jak Zahy Hadid czy Franka Ghery, mogą odżegnywać się od poprzedników, ale może mimowolnie kontynuują to, co narodziło się na początku XX wieku.

Stowa kluczowe: ekspresjonizm, architektura, rzeźba, dekompozycja

* Ph.D. Arch. Tomasz Kozłowski, Department of Housing Architecture and Architectural Composition, Faculty of Architecture, Cracow University of Technology. 
It is difficult to define expressionist sculpture as a uniform style. The authors of The Encyclopedia of Expressionism tried to find two artistic trends making it easier to state its definition precisely. "One outlook prevailed among the German critics: sculpture revealed a considerable dose of openness to expressionism or rejected the existing conventions. According to the other outlook, expressionism means intensive expressiveness of forms going to such extremes as deformation and abstraction which results from an artist's inner need". Expressionist sculpture created by artists belonging to the Die Brücke group, remained under the influence of primitive art. These authors explained their interest with the "primeval" expression of such works. Their creations often imitated African statuettes in a literal manner. Here again, artists talked about abandoning the past, meaning the immediate past, as usual. "The entire art of the late nineteenth century called art pompier, characterized by shameless odalisques, the nudity of classical deities as well as exaggerated historical references, can be easily identified as kitsch"2. Twentieth-century creation was expected to be different, free from passeism, more ideological, unorthodox and original. We can assume that an artist's desire for the internal dynamics of a given work became a shared feature. That kind of art combined various creative tendencies and included the achievements of such authors as Picasso, Barlach or Archipenko.

Such a "primitive" style, which rejected the existing conventions of picturing destruction, ruins and absence in a metaphorical but also literal manner, can be exemplified by Ossip Zadkine's sculpture entitled The Torn City also known as The Destroyed City (1951-1953). The artist, defined as a post-cubist, created it by drilling the volumes deeply and producing a profoundly bombastic form ${ }^{3}$. Zadkine's monument shows a human figure decomposed in the cubistic manner. In this case, we can say that the dramatic monument to the ruined city is a ruin or perhaps an expression itself. Certainly, this work is expressive and full of curves - it bears the artist's humane message concerning World War II and the bombings of the centre of Rotterdam in 1940. "Today's young sculptor will borrow the daring concept of spontaneity and genuine freedom from Negro art in order to reach EXPRESSION"4. In 1994, Philip Johnson designed the visitor pavilion Glass House in New Canaan, Connecticut. The author called this building, or maybe sculpture, Da Monsta which means a monster in hip-hop slang. It was constructed from plastered concrete laid upon a steel net. Provides an introduction to Johnson's work. The entire estate together with some pavilion houses, a guesthouse, a painting gallery, a sculpture gallery and a library act as a museum these days. The entrance building itself consists of two intermingling irregular volumes with sharp edges. The middle is just the waiting room and the projection room. The author admits that he was inspired by Hermann Finsterlin's art. However, it may be his authorial interpretation of the expressionism of the early twentieth century. The bodies forming a part of this composition as well as the colours of the "elevations" become aggressive. Their redness and greyness help a visitor to find the shapes which formed this

\footnotetext{
${ }^{1}$ L. Richard, Encyklopedia ekspresjonizmu, Warsaw 1996, 136.

2 U. Eco, Historia brzydoty, Poznan 2007, 400.

3 A. Borzeskowska, Całkiem nowe ruiny. Między romantyzmem a postmodernizmem, „Arteon” 2002, No. 5, 44-45.

4 A. Kotula, P. Krakowski, Rzeźba współczesna, Warsaw 1980, 117.
} 
pavilion. The work proves that a new monument need not be large - it can have a "regular" human scale.

In the other outlook, one can search out some inspirations for the minimalist sculpture The Broken Obelisk (1967) created in Houston by an artist from the circle of abstract expressionism - Barnett Newman. It shows an elegant composition of "post-elementary" volumes against the background of an equally smart modernist architecture without causing discomfort through its instability. The artist moves towards abstraction but the onlooker's attention is temporarily occupied by the "chipped" top of the slender quadratic prism which crowns the composition with its unreliable spot support. The following questions arise: Is this the beginning of an interrupted composition or the closing of a ruined one? Was the whole the basis for something bigger or can this thing be continued like The Endless Column by Constantine Brancusi? The present time has given architects some tools for creating new structures that could not be built by the expressionists of the early twentieth century. Philip Johnson and John Burgee raised twin towers Puerta de Europa I and Puerta de Europa II - two leaning prisms, 114 metres tall, 15 degrees off the vertical - on one of Madrid's boulevards. The chequered elevation of dark glass is decorated with a glittering frame in the corners of the building and in its centre. The slanting elevations are reinforced with some intersecting elements. Both towers are supported by enormous counterweights which facilitated construction. The structures were conceived as one spatial layout jointly creating a gateway to Europe and a new street perspective. A struggle against the gravitational forces forms the first leaning skyscrapers. Similarly to The Broken Obelisk, they fight with nature and win.

Maria Misiągiewicz describes Hermann Finsterlin's achievements: “...He treated a structure as a pointless and unequaled game of sublime forces included in rough matter frozen at the moment of the most profound reflection"5. As a young architect, Finsterlin created a number of utopian house designs. He was not an architect by profession. He decided to take up art after he had climbed Mount Watzmann at night and discovered the beauty of nature. In 1919, Walter Gropius invited him to take part in an exhibition of the Unknown Architects organized in Berlin. Similarly to Scharoun, Finsterlin created utopian designs but - contrary to Scharoun - he never managed to realize his visions. His designs were presented as clay sculptures, sharp, pointed, without right angles, sometimes resembling crystals. As Dennis Sharp writes, Finsterlin treated a building as a work of all the arts, a gigantic empty sculpture with unlimited possibilities of shaping the outside and the inside as well as only one requirement of esthetical balance. ${ }^{6}$ Such gesamtkunstwerk is expressed in a combination of various domains of art: literature, painting, music, architecture. Finsterlin was also a poet, an essayist and a composer after all. The new approach to design was caused by his prophetic dream where he saw a completely new type of architecture with colourful bent walls, so different from the primitive cuboidal dwelling structure. The impact of such an outlook on architecture is still noticeable. While admiring the designs of The Mausoleum (1919) or The Little Guesthouse (1921), an association with some implemented designs by Coop Himmelb(1)au, Zaha Hadid or Frank Gehry comes to mind. Coop Himmelb(1)au's Pavilion 21 MINI Opera

\footnotetext{
5 M. Misiągiewicz, O prezentacji idei architektonicznej, Krakow 1999, 114.

6 D. Sharp, Modern Architecture and Expressionism, New York 1966, 98.
} 
Space (2008-2010) was built for the needs of the Munich Opera Festival 2010. Władysław Tatarkiewicz's comments explaining various meanings of the word "beauty" could be its motto. The philosopher presented it as five definitions which best match the theory of beauty. "Namely: 1) Beauty is a simple quality characteristic of some things; 2) it is a particular shape characteristic of some things; 3 ) it is what arouses certain special emotions in people; 4) it is the manifestation of a commonplace (typical, ideal) factor in a thing; 5) it is expression"7. The building is small and lacks decorations in the ordinary sense of the word. However, it becomes the essence of ornamentation itself. Its form is to correspond with the assignments it received. It is to be a place for a quest for new ways of perceiving art. The area is not big $\left(560 \mathrm{~m}^{2}\right)$ and has seats for 300 people only. The volume was shaped - as the authors claim - with a computer simulation of Jimi Hendrix's song Purple Haze and the passages from Mozart's Don Giovanni. Ideologically, this work resembles the Philips expositional pavilion designed by Le Corbusier in 1958. The building is an eyesore just like Finsterlin's sculptures. On one hand, it encourages the passers-by to come closer and look at themselves in the polished metal; on the other hand, it scares them away like a fortress. However, the authors do not distance themselves from the functional explanation of the form of their work which is supposed to absorb the noise from the neighbouring streets. The musical connotations are also important here considering the fleetingness of this work which, despite its considerable size, was disassembled and moved to another location to create a new category: "mobile architecture". Referring to Wolf D. Prix's words "Architecture should embrace, be passionate, smooth, hard, with sharp corners. It must be brutal, rounded, gentle, colourful, obscene, tempting, dreaming, alluring, surpassing, wet, dry, with a heartbeat. It has to be vital or lifeless. If it is cold, it must be stone-cold; if it is hot, it has to be as hot as fire. Architecture must burn", we could add that it should be an eyesore, too.

In 1921, Walter Gropius designed Denkmal der Märzgefallenen (The Monument to the Casualties of the Kapp Putsch) whose form resembles an overturned obelisk with a pyramid on top. However, it was built of concrete instead of stone. It was conceived to present a thunderbolt as a symbol of life. It was raised in 1922 and then destroyed by the fascists; its replica still stands on the grounds of the cemetery in Weimar. This work can make the prototype for Pavilion 21. Its form is uncompromising - with no ornaments, sharp, indicating the direction toward the sky. It could be explained with Pierre Francastel's words: "Thus, a work of art is essentially an object of special nature, an imaginary object, i.e. a kind of sign transmitter which is not a pattern, an image which appeared in an artist's mind, a picture he formed at the end of his work or an original image that emerges in every onlooker's head. Since it includes this margin of indefiniteness, it can show specific yet fragmentary starting points. Moreover, it can express communicative reactions making us aware of one of the crucial features of a work of art and one of the possible tangent points between such apparently distant forms as an image and a building" ". In this case, a sculpture appears somewhere between an image and a building. The work looks as if it was moving - it is dynamic like in a motion picture. We do not know if this form goes up or down;

\footnotetext{
7 W. Tatarkiewicz, Dzieje sześciu pojęć, Warsaw 1975, 138.

8 Coop Himmelb(1)au, Architektur muß brennen, Graz 1980, V.M. Lampugnani, op. cit., 116.

9 P. Francastel, Sztuka a technika, Warsaw 1966, 275.
} 
it becomes an expression of movement. The recipient feels like coming nearer and sustaining the monument to save it from inescapable destruction. Perhaps it is a reminiscence of the strictly expressionist painting The Sea of Ice (1823-1824) by the Romantic German artist Caspar David Friedrich. Looking at it, we are also uncertain if the ship was destroyed by the ice banks or absorbed by the concrete car park at the supermarket. "The assignment of art is not to facilitate general harmony but to come as a shock" ${ }^{10}$. These words uttered by the writer and poet Walter Husenclaver could act as the motto of contemporary art.

Expressionist sculpture had a strong impact on architecture. Hans Poelzig's design of Grosses Schauspielhaus (1919) in Berlin is one huge monument. Hermann Finsterlin's buildings assumed the form of sculptural models only. Mendelsohn's design of Einsteinturm includes independent sculptures instead of an architectural model. Both Zaha Hadid and Frank Gehry's contemporary buildings are already constructed expressionist sculptures distinguished by their monumental scale, not by their form. The present day always pretends that it is not looking for the origins, but this is nothing but an artistic delusion. Creators try to avoid being accused of copying things which is understandable but we are always left with some aftersights, with a fugitive inspiration drawn from what used to be. Obviously, it is a blurred image - we are not always capable of seeing the original because we can remember the shape yet in different colours. If we treat the present state of architecture as evolution, we must not forget that evolution has no purpose. What we are observing right now was unpredictable to those who lived and worked in the early twentieth century. Let us quote Heinrich Wölfflin's words cited by Ernst Gombrich in his ruminations on the psychology and mystery of styles which may become the motto of the return to expressionist art: "Not everything is possible at every time"11, or Viollet-le-Duc's statement: "If the Gothic constructors had been able to use cast iron in large bars, they would have willingly mastered this technique necessary for making buttresses as slender and durable as possible. Perhaps they would have applied them more appropriately than we do"12. These days, owing to new building technologies and computers, we can fulfill our predecessors' dreams. Contemporary architects have joined the artistic community, whereas the models of their houses or stadiums can be exhibited at museums beside sculptures created by the futurists and expressionists of the early twentieth century with no shame at all. We might venture a thesis on the appearance of a new tendency in contemporary art - architectural sculpture as an esthetical category unrelated to the function or scale of a work but related to its form.

\footnotetext{
${ }^{10}$ W. Husenclaver, Zadania teatru, in Ekspresjonizm w teatrze europejskim, Warsaw 1993, 250.

${ }^{11}$ E.H. Gombrich, Pisma o sztuce i kulturze, selected and edited by R. Woodfield, Krakow 2011, 84.

${ }^{12}$ E. Viollet-le-Duc, Dictionnaire raisonné de l'architecture française du XIe au XVIe siècle, E. Porębska, M. Poprzęcka, Teoretycy, artyści i krytycy o sztuce 1700-1870, Warsaw 1989, 470-471.
} 


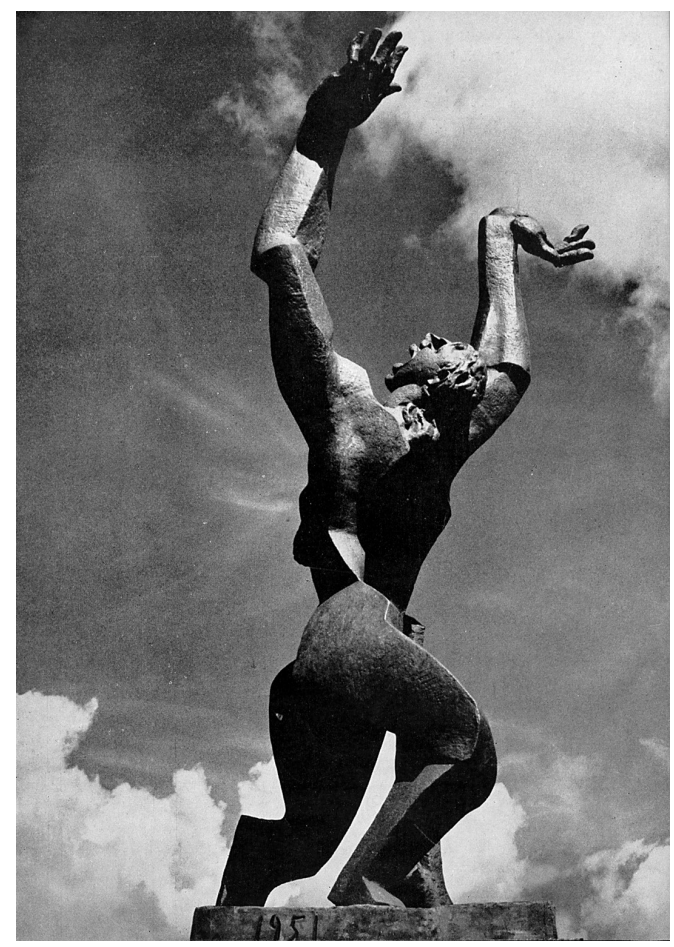

Ill. 1. Ossip Zadkine, The Torn City of Rotterdam, The Netherlands 1953 (Rotterdam Der neubau einer Stadt, edited by C. Van Traa)

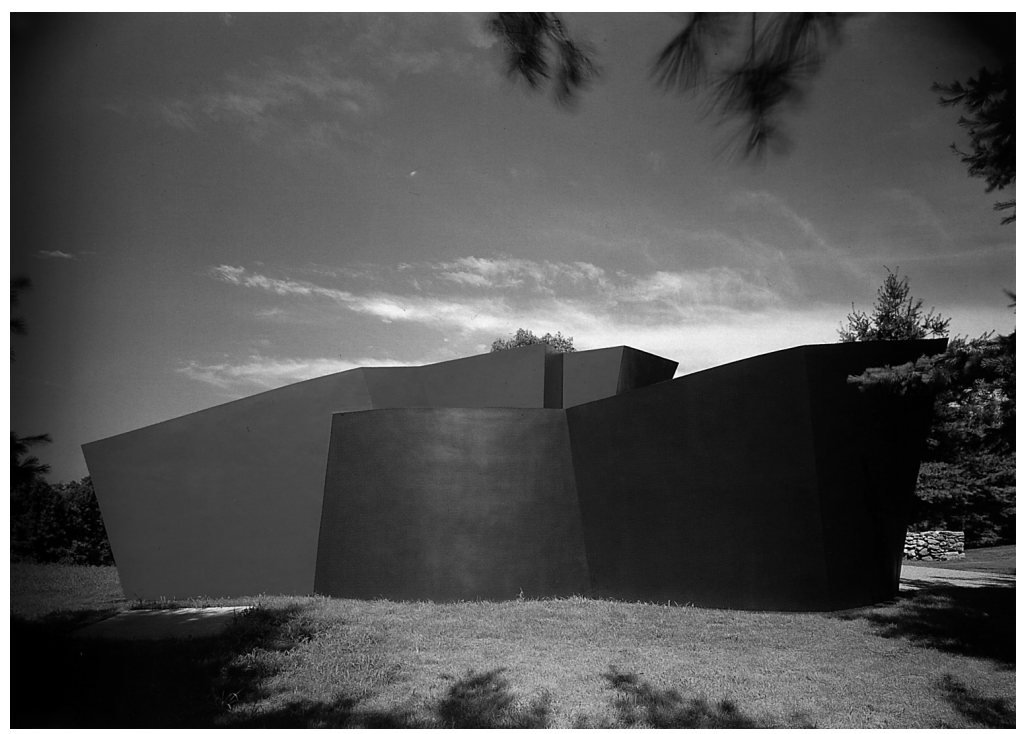

Ill. 2. Philip Johnson, Visitor's pavilion, New Canaan, Connecticut, 1994 (“Domus”, February 1996) 


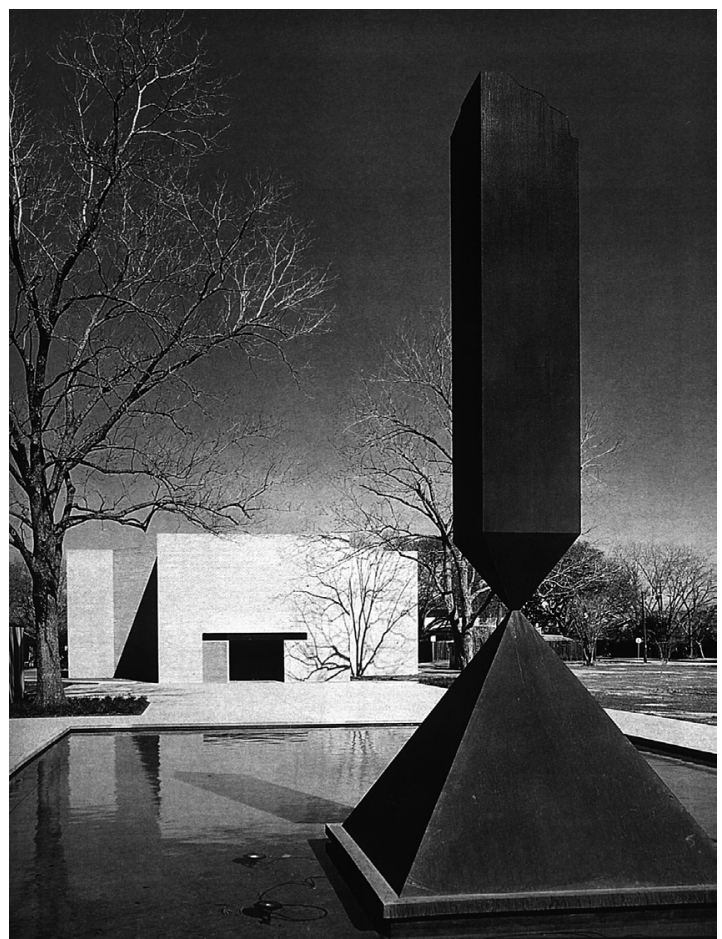

Ill. 3. Barnett Newman, The Broken Obelisk, Houston, 1967 (Wojciech Włodarczyk, W poszukiwaniu istoty. Minimal-art i konceptualizm, [In:] Sztuka świata, tom 10, Warszawa 1996)

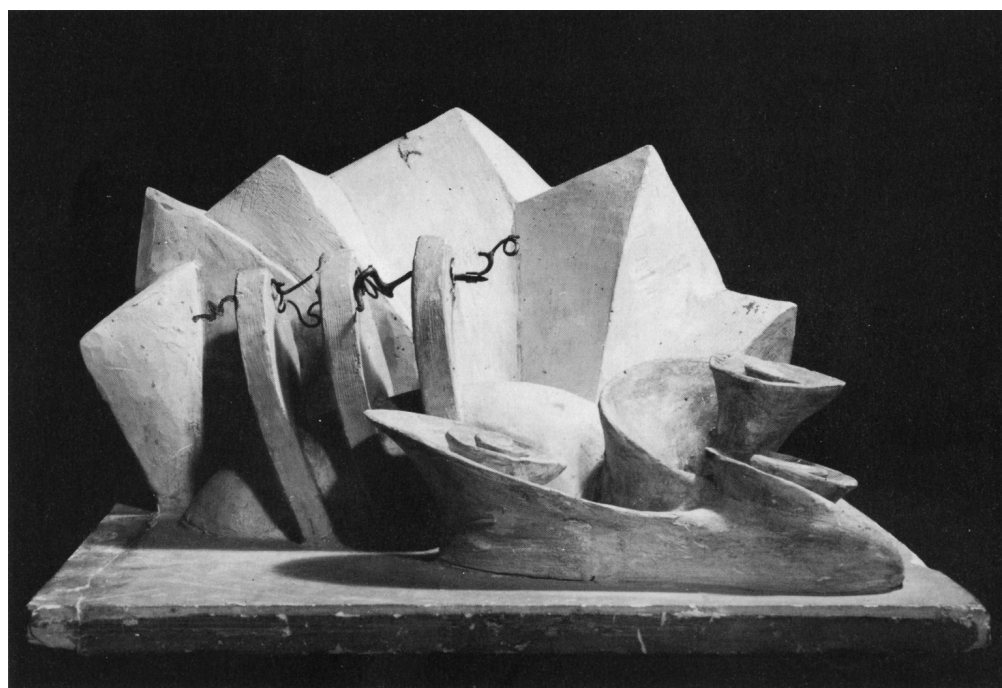

Ill. 4. Hermann Finsterlin, Mausoleum, 1919 (Dennis Sharp, Modern Architecture and Expressionism, New York 1966) 


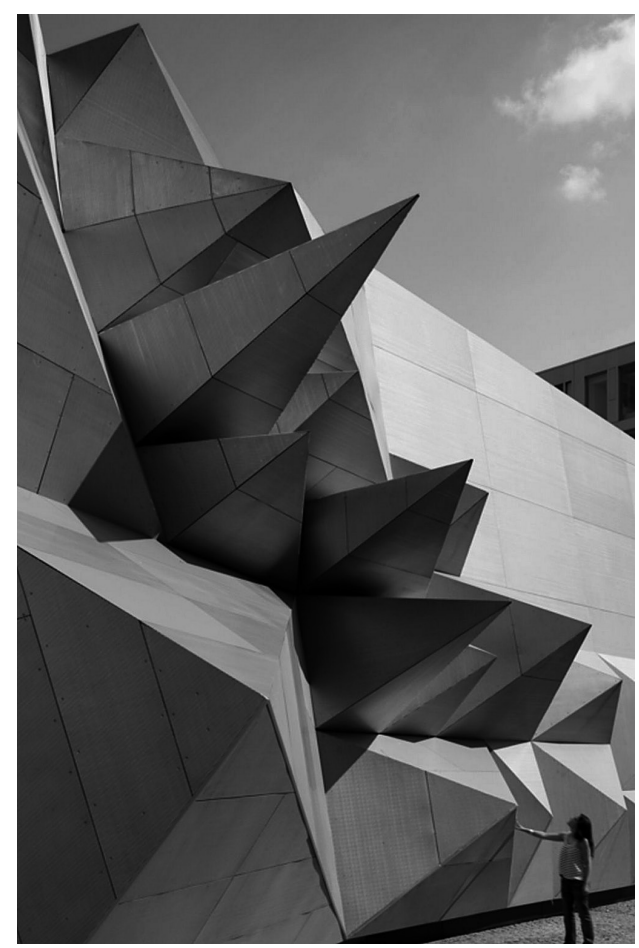

Ill. 5. Coop Himmelb(1)au, Pavilion 21 MINI Opera Space (Munich Opera Festival 2010, Munich, Germany, 2008-2010)

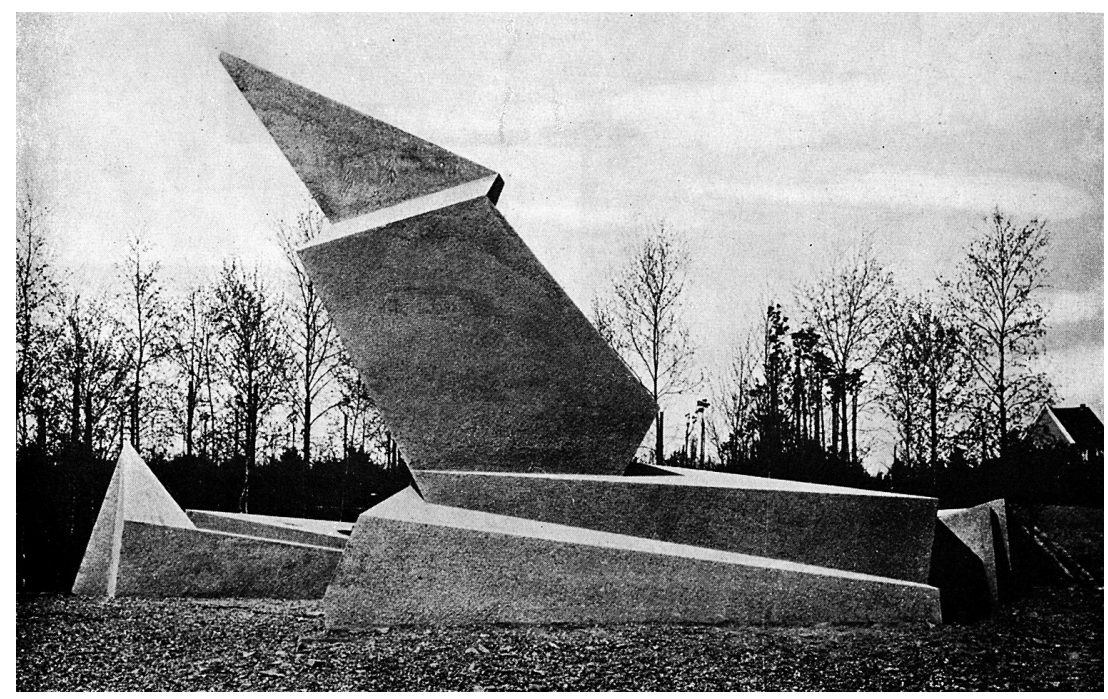

Ill. 6. Walter Gropius, The Monument to the Casualties of the Kapp Putsch, 1921 (Werlag Gerd Hatje, Bauhaus Weimar 1919-1925 Dessau 1925-28, Stuttgart 1955) 


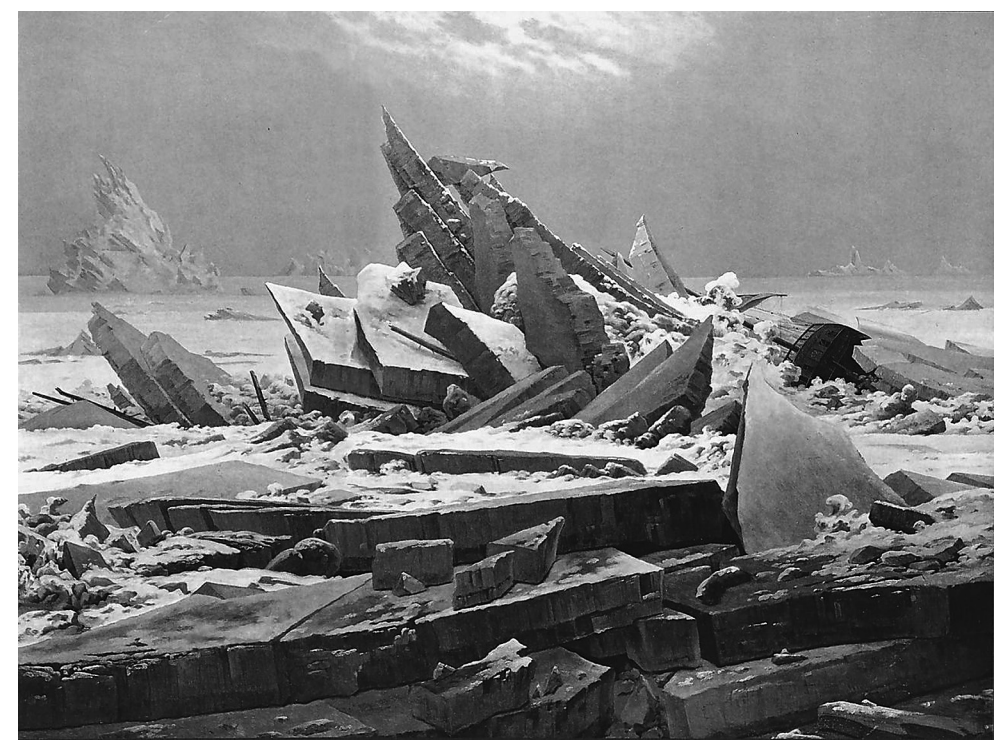

I1l. 7. Caspar David Friedrich, The Sea of Ice, 1823-1824, oil paint 